\title{
PEMENUHAN HAK ANAK DALAM BUKU SISWA KELAS LIMA SEKOLAH DASAR KURIKULUM 2013
}

\author{
Wahdan Najib Habiby ${ }^{1}$ dan Ika Candra Sayekti ${ }^{2}$ \\ PGSD FKIP Universitas Muhammadiyah Surakarta \\ ${ }^{1}$ wnh122@ums.ac.id; ${ }^{2}$ ics142@ums.ac.id
}

\begin{abstract}
The aim of this research was to investigate whether students' text book Grade 5 Theme I in Curriculum 2013 has been fulfill child right in learning process or not. It was library research through qualitative approach, and using descriptive analytic method. The result of this study showed that Indonesian government has consistently applied the 1989 UN children right convention result, both juridically and applicatively. It can be seen on students'text book Grade V Theme I Curriculum 2013 which has been fulfill child right but it is required to be actualized more in real learning process by the teacher.
\end{abstract}

Keyword: child right content, Students book, Curricullum 2013

\section{PENDAHULUAN}

Pendidikan merupakan kebutuhan dasar bagi setiap individu dan menempati posisi yang sangat strategis dalam mencerdaskan kehidupan bangsa. Kesadaran terhadap pentingnya aspek pendidikan bagi sebuah negara tidak cukup dipahami secara material, seperti menaikkan anggaran pendidikan dalam APBN. Hal yang jauh lebih penting dari masalah anggaran adalah konstruk penyelenggaraan pendidikan nasional yang berlandaskan pemenuhan hak-hak peserta didik. Karena secara logis sekolah yang diperuntukkan bagi siswa (anak-anak) hendaknya dibangun diatas kepentingan anak, bukan atas kepentingan orang dewasa yang seringkali hanya mengutamakan capaian prestasi anak.

Hasil konvensi hak-hak anak United Nations Convention on the Right of The Child/CRC pada tanggal 20 November 1989, anak didefinisikan sebagai "setiap manusia yang berusia di bawah 18 tahun". Sedangkan menurut Undang-undang Perlindungan Anak No. 23 Tahun 2002, anak wajib diberi perlindungan secara menyeluruh sejak dalam kandungan. Dengan demikian anak adalah manusia yang sejak berada dalam kandungan sampai usia 18 tahun. Perlindungan secara menyeluruh yang dimaksud dalam undangundang meliputi tiga hal, yaitu: provisi, proteksi dan partisipasi.

Provisi memiliki arti menyediakan dan memenuhi kebutuhan anak seperti pendidikan, makanan, kesehatan, tempat tinggal, dll). Proteksi berarti melindungi anak dari kekerasan fisik, kekerasan verbal, kekerasan psikis, penelantaran, dan eksploitasi. Sedangkan partisipasi bermakna memberikan kesempatan kepada anak untuk berpartisipasi aktif dalam setiap kegiatan yang melibatkan dirinya, seperti dalam pendidikan, pembelajaran, dan penentuan aturan. Secara eksplisit ketiga hal tersebut diuraikan baik dalam teks konvensi PBB maupun dalam Undang-undang Perlindungan Anak.

Habiby (2012) dalam penelitiannya menemukan dari 47 siswa kelas VI SDN Tahunan Yogyakarta mengalami stres dalam 
menjalani program sekolah untuk mempersiapkan diri menghadapi ujian nasional 2012 dengan level sedang 53,2\% (25 siswa) dan ringan $46,8 \%$ (22 siswa). Stres siswa tersebut berimplikasi pada aspek emosi $42,92 \%$, diikuti aspek pikiran 39,35\%, aspek fisik 35,94\%, dan aspek perilaku 34,54\%. Program sekolah tersebut adalah penambahan jam belajar setiap hari dari senin sampai sabtu selama 4 jam untuk mengulas materi mata pelajaran yang di uji nasionalkan dari kelas 3 - 6 SD. Metode drill yang diterapkan sekolah didukung dengan rendahnya pengetahuan guru dan kepala sekolah tentang stres pada anak menjadi stressor terbesar.

Gambaran tentang kondisi anak didik di SD Tahunan di atas adalah satu dari sekian banyak kasus pengabaian hak-hak anak yang terjadi di sekolah. Pengabaian tersebut biasanya dilakukan dengan berbagai alasan, seperti memberikan hukuman fisik dan psikis dengan alasan mendisiplinkan; memberikan terlalu banyak materi pembelajaran dengan alasan tuntutan kurikulum; memberikan pekerjaan rumah yang banyak dengan alasan agar siswa mau belajar; pendidikan yang terlalu berpusat pada guru dengan alasan siswa belum mampu memahami materi; pendapat siswa tidak dihargai dengan alasan pendapatnya salah; dan lain sebagainya.

Komisi Perlindungan Anak Indonesia (KPAI) menyadari bahwa selama ini penyelenggaraan pendidikan di Indonesia belum dibangun dengan pemenuhan hak-hak anak, oleh karena itu mereka mendesak untuk menjadikan konsep sekolah ramah anak menjadi kebijakan nasional yang diadopsi oleh seluruh sekolah agar anak bisa belajar dengan nyaman, senang, tentram, tidak terancam, menumbuhkan karakter dan mandiri. Merespon masukan dari mayarakat akan pentingnya sekolah yang ramah anak, maka pemerintah menyusun perangkat hukumnya melalui Peraturan Menteri Negara Pemberdayaan Perempuan dan Perlindungan Anak Nomor 8 Tahun 2014 tentang Kebijakan Sekolah Ramah Anak.

Keberadaan sekolah ramah anak tidak bisa terlepas dari poin-poin yang terdapat dalam hasil Konvensi PBB tentang hak-hak anak dimana sekolah ramah anak adalah sekolah yang secara sadar berupaya menjamin dan memenuhi hak-hak anak dalam setiap aspek kehidupan secara terencana dan bertanggungjawab. Prinsip utama dari sekolah ramah anak adalah tidak terdapat diskriminasi kepentingan, pemenuhan hak hidup serta penghargaan terhadap anak. Secara implisit penyelenggaraan sekolah ramah termuat dalam pasal 28, 29, dan 31 konvensi hak anak PBB. Poin penting dari ketiga pasal tersebut adalah: 1) pendidikan berpusat pada anak, penegakan disiplin dengan memperhatikan martabat dan harga diri anak, dan pengembangan kapasitas anak; 2) pengembangan keterampilan, pembelajaran, kemampuan lainnya, martabat manusia, harga diri, dan kepercayaan diri; 3) pengembangan kepribadian, bakat, dan kemampuan untuk hidup dalam kehidupan di masyarakat; 4) hak anak untuk pendidikan tidak hanya masalah akses, tetapi konten; dan 5) hak anak untuk pemanfaatan waktu luang dan kegiatan budaya.

Penerapan konsep sekolah ramah anak sebagaimana tercantum dalam poin 4 di atas menyebutkan bahwa hak anak untuk pendidikan tidak hanya masalah akses, namun juga masalah konten. Konten yang dimaksud adalah materi pelajaran yang di ajarkan kepada siswa, yaitu susunan materi yang ada dalam buku/bahan ajar siswa. 
Sejak tahun 2013 pemerintah Indonesia menerapkan kurikulum nasional baru yang dikenal dengan kurikulum 2013. Pengembangan Kurikulum 2013 merupakan langkah lanjutan Pengembangan Kurikulum Berbasis Kompetensi yang telah dirintis pada tahun 2004 dan KTSP 2006 yang mencakup kompetensi sikap, pengetahuan, dan keterampilan secara terpadu. Dengan visi anak Indonesia yang cerdas, ceria, berakhlak, dan berhati mulia. Pemerintah memperkenalkan Kurikulum 2013 yang berfokus pada "Pendidikan" dan "Kebudayaan" yang ditujukan untuk menghasilkan anak yang memiliki pengetahuan, keterampilan, dan sikap untuk menghadapi kehidupan masa kini dan masa depan.

Kompetensi yang diharapkan dari lulusan SD/MI dalam kurikulum 2013 adalah kemampuan pikir dan tindak yang produktif dan kreatif dalam ranah abstrak dan konkret. Kemampuan itu diperjelas dalam kompetensi inti, yang salah satunya, "menyajikan pengetahuan dalam bahasa yang jelas, logis dan sistematis, dalam karya yang estetis, atau dalam tindakan yang mencerminkan perilaku anak sehat, beriman, berakhlak mulia". Kompetensi itu dirancang untuk dicapai melalui proses pembelajaran berbasis penemuan (discovery learning) melalui kegiatan-kegiatan berbentuk tugas (project based learning), dan penyelesaiaan masalah (problem solving based learning) yang mencakup proses mengamati, menanya, mengumpulkan informasi, mengasosiasi, dan mengomunikasikan

(Kementerian Pendidikan dan Kebudayaan, 2014: ii).

Sejak ditetapkannya hasil konvensi PBB tentang hak-hak anak secara Internasional tahun 1989, banyak Negara meratifikasi hasil konvensi termasuk Indonesia, melalui
Keputusan Presiden Nomor 36 Tahun 1990 pada tanggal 25 Agustus 1990. Berdasarkan keputusan presiden tersebut selanjutnya diratifikasi ke dalam Undang-undang Tentang Perlindungan Anak Nomor. 23 Tahun 2002 dan telah dilakukan revisi melalui Undang-undang No. 35 tahun 2014 Tentang Perubahan Atas Undang-undang Perlindungan Anak.

Pemerintah Indonesia juga menerbitkan Peraturan Menteri Negara Pemberdayaan Perempuan dan Perlindungan Anak Nomor 8 Tahun 2014 tentang Kebijakan Sekolah Ramah Anak. Sedangkan untuk memobilisasi dan percepatan tersedianya sekolah ramah anak di Indonesia maka pemerintah menerbitkan Peraturan Menteri Negara Pemberdayaan Perempuan dan Perlindungan Anak Nomor 12 Tahun 2011 tentang Indikator Kabupaten/Kota Layak Anak.

Keseriusan negara dalam memenuhi hakhak anak juga dilakukan oleh Skotlandia, pada tahun 2008 telah menerbitkan buku panduan pemenuhan hak-hak anak secara nasional dengan judul "A Guide To Getting It Right for Every Chil: How to Implementing" dan disusul dengan penerbitan buku kedua pada tahun 2010 yang berjudul " A Guide To Implementing Child Right In Scotland" yang berisi tentang panduan secara sistematis pemenuhan hak-hak anak didunia pendidikan yang meliputi: Changing System; Changing; Practice; Implementing Change; and Changing Culture (The Scottish Goverment, 2010).

Swedia melalui SIDA dan Lund University sejak tahun 2001 secara konsisten membangun sekolah ramah anak dengan empat prinsip dasar, yaitu: nondiscrimination; The Best Interest of The Child; Right to Participation; and Right to Life and Development. Keempat prinsip dasar 
tersebut harus diimplementasikan dalam sekolah ramah anak dengan: a) merubah arah proses pengajaran dan pembelajaran dari konsep top down (kebijakan sekolah/pemerintah/guru untuk siswa) menjadi konsep button up (dari siswa untuk dilakukan bersama-sama); b) merubah pendekatan pengajaran dan pembelajaran dari teacher centre menjadi student centre. Sehingga posisi guru bukan lagi sebagai sumber informasi tetapi sebagai fasilitator pendidikan; c) kelas bukan hanya sebagai tempat pengajaran teoritis, tetapi harus menampakkan potret kehidupan sosial sesungguhnya yang dialami oleh manusia; d) konsep transfer pengetahuan yang dijalankan harus mengandung interaksi yang hangat antar sesama siswa, guru, dan kondisi dunia yang sesungguhnya secara luas (Leo ULF, at all, 2014: 18-20).

Konsep sekolah ramah anak yang ditawarkan oleh beberapa negara pada dasarnya sesuai dengan pandangan aliran konstruktivisme, yang menyatakan bahwa pembelajaran yang baik perlu dilaksanakan dengan melibatkan interaksi banyak pihak dan harus mampu menjadikan kelas pembelajaran sebagai micro social system. Vygotsky (1978) menyebutkan empat hal yang wajib dilakukan dalam pelaksanaan pembelajaran di kelas, yaitu eksperience, understanding, skill, and Facts.

Desain pembelajaran di kelas yang menghadirkan konsep micro social system dan mengandung kegiatan eksperience, understanding, skill, and facts sesungguhnya sudah terakomodir dalam konsep kurikulum 2013 untuk sekolah dasar di Indonesia dengan pendekatan tematik integratif.
Penerapan pendekatan tematik integratif telah memberikan peluang bagi guru untuk memenuhi empat konten yang disarankan oleh Vygotsky, namun sukses dan tidaknya pelaksanaan pembelajaran dikelas dalam kurikulum 2013 terletak pada bagaimana guru mengimplementasikannya, dan bagaimana konten bahan ajar disusun serta disampaikan secara sistematis.

Konstruk kurikulum 2013 untuk sekolah dasar yang telah disusun pemerintah Indonesia tersebut tentunya juga harus memperhatikan hak-hak anak baik dalam pelaksanaannya maupun dalam konten bahan ajarnya. Merujuk pada dokumen konvensi hak anak PBB tahun 1989, Undang-undang No. 35 tahun 2014 Tentang Perubahan Atas Undang-undang Perlindungan Anak, dan Peraturan Menteri Negara Pemberdayaan Perempuan dan Perlindungan Anak Nomor 8 Tahun 2014 tentang Kebijakan Sekolah Ramah Anak, ada beberapa hal yang berkaitan secara langsung dengan pembelajaran di sekolah, yaitu: konsep sekolah ramah anak, pembelajaran, dan evaluasi.

Secara sederhana konsep pembelajaran ramah anak yang terkandung dalam CRC tahun 1989, Undang-undang dan Peraturan Perundang-undangan di Indonesia disajikan dalam tabel 1. Pada poin 4 konsep sekolah ramah anak menyebutkan bahwa hak anak untuk pendidikan tidak hanya masalah akses, namun juga masalah konten. Konten yang dimaksud adalah materi pelajaran yang di ajarkan kepada siswa, yaitu susunan materi yang ada dalam buku/bahan ajar siswa. 
Tabel 1. Konsep Pembelajaran Ramah Anak Dalam CRC 1989, Undang-Undang dan Peraturan Perundang-undangan di Indonesia.

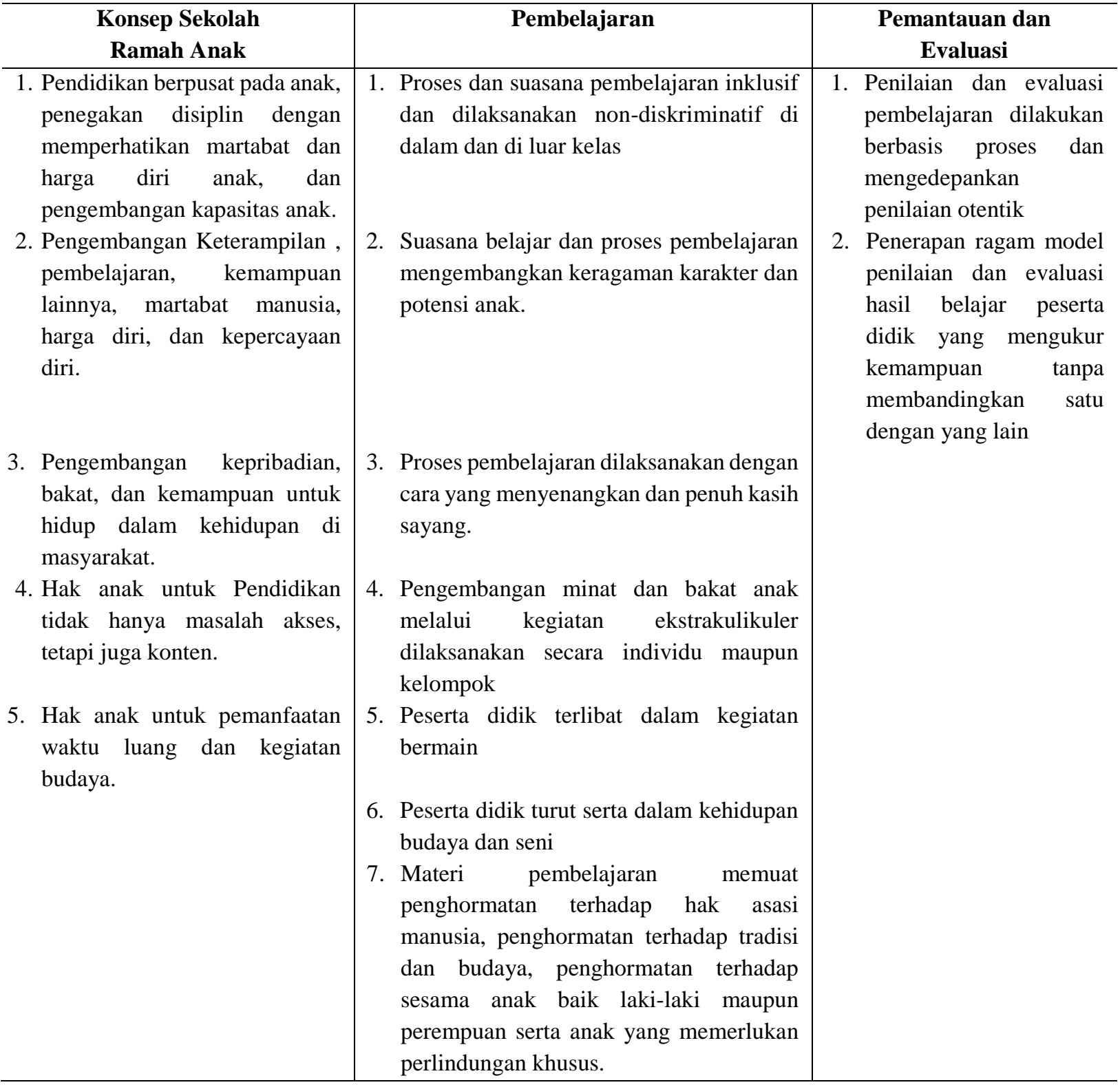

Berdasarkan hasil kajian kepustakaan, indikator pemenuhan hak anak yang terdapat dalam buku ajar dapat dijabarkan sebagai berikut:

1) Provison: Bebas berpendapat sesuai dengan hasil telaah siswa dari berbagai sumber belajar; bebas berekspresi; bebas mengakses media dan sumber pembelajaran; Pembelajaran inklusif dan non diskriminatif; Penilaian dan evaluasi dilaksanakan berbasis proses dan mengedepankan penilaian otentik.

2) Proteksion: berpusat pada siswa, disiplin dengan memberikan perhatian hargadiri anak, mengembangkan kapasitas siswa; Materi pembelajaran memuat penghormatan terhadap agama dan hak asasi manusia; Materi pembelajaran 
memuat penghormatan kepada sesama anak (termasuk anak-anak yang berkebutuhan khusus); Materi pembelajaran memuat penghormatan terhadap tradisi dan budaya bangsa.

3) Partisipation: Learning by doing; Keterlibatan aktif siswa dalam belajar dan bermain; Pengembangan kepribadian, bakat, dan kemampuan untuk hidup dimasyarakat; Pengembangan keterampilan (menyelesaikan masalah, berpikir, belajar mandiri); menghargai martabat manusia, harga diri; dan membangun kepercayaan diri.

Dalam rintisan implementasi kurikulum 2013 pemerintah menyediakan dua jenis buku yaitu buku untuk guru dan buku untuk siswa. masing-masing buku digunakan sebagai acuan pembelajaran dalam pelaksanaan pendidikkan Nasional yang harus digunakan secara penuh, baik oleh siswa maupun oleh guru. Keberadaan buku ajar tersebut menarik untuk dikaji apakah bahan ajar yang disusun pemerintah sudah mengandung konten-konten yang ramah terhadap anak. Hal tersebut penting dilakukan untuk melihat keseriusan dan konsistensi pemerintah dalam membangun sistem pendidikan di Indonesia yang ramah terhadap anak sesuai amanah Undangundang dan peraturan perundang undangan yang berlaku di Indonesia. Oleh karena itu, makalah ini mencoba mencari konten hakhak anak pada buku siswa dengan batasan buku siswa kelas 5 sekolah dasar dengan tema "Benda-benda Dilingkungan Sekitar".

\section{METODE PENELITIAN}

Penelitian ini adalah penelitian kualitatif dengan jenis penelitan kepustakaan (library research) dan menggunakan metode deskriptif-analitis (Bakker dan Anton Zubair 1990: 53), sehingga fakta-fakta yang diperoleh dari kajian kepustakaan akan disajikan secara teratur dan sistematis sebagaimana konsep yang dibangun dalam buku siswa kelas lima SD, sehingga dengan mudah dapat dipahami. Sedangkan analitis adalah melakukan pemeriksaan secara konsepsional atas makna yang dikandung oleh istilah yang digunakan dan pernyataan yang dibuat (Kattsoff, 1987: 18), dalam hal ini peneliti akan menganalisis (memahami dan menjelaskan) konten buku siswa kelas lima SD pada kurikulum 2013 yang dihubungkan dengan hak-hak anak yang tercantum dalam konvensi PBB, Undang-undang, dan Peraturan perundang-undangan di Indonesia.

Penelitian ini tidak bermaksud untuk menghasilkan pemahaman baru (inventif) tentang konten hak-hak anak pada buku siswa kelas 5 dengan tema "Benda-benda Disekitar Siswa", akan tetapi memberikan penjelasan secara teratur dan sistematis tentang konten yang berkaitan dengan hak-hak anak pada buku siswa kelas lima (Anton Bakker dan Achmad Charis Zubair 1990: 16-17), sehingga penelitian ini akan menampilkan konten buku apa adanya secara objektif.

Objek formal dari penelitian ini adalah berbagai pandangan tentang konsep dan konten bahan ajar yang berkaitan dengan pemenuhan hak-hak anak di lingkup sekolah, sedangkan objek materialnya adalah buku siswa kelas lima kurikulum 2013 dengan tema Benda-benda dilingkungan sekitar siswa (Anton Bakker dan Achmad Charis Zubair 1990: 35-36). Dalam penelitian ini tidak akan memberikan pembahasan secara mendalam tentang konsep sekolah ramah anak, melainkan pembahasan secara spesifik tentang konten buku siswa kelas lima sekolah dasar secara ringkas. 


\section{HASIL DAN PEMBAHASAN}

Materi Pembelajaran dalam buku siswa kelas lima SD pada semester satu memuat 5 tema (lima buku siswa dan lima buku guru). Tiap tema terdiri atas 3 subtema yang diuraikan ke dalam 6 pembelajaran. Satu pembelajaran dialokasikan untuk 1 hari. Tiga subtema yang ada direncanakan selesai dalam jangka waktu 3 minggu. Pada minggu ke-4 diisi dengan berbagai kegiatan yang dirancang sebagai aplikasi dari keterpaduan gagasan pada subtema 1-3. Kegiatan pada minggu terakhir diarahkan untuk mengasah daya nalar dan kemampuan berpikir tingkat tinggi. Penelitian ini hanya dilakukan pada tema satu buku siswa kelas lima sekolah dasar yaitu "Benda-benda di Lingkungan Sekitar".

Buku siswa ini disusun dengan huruf Baar Metanoia, menggunakan ukuran 12 pt dan memuat rencana pembelajaran berbasis aktivitas. Capaian kompetensi diharapkan secara terpadu yaitu mempelajari semua mata pelajaran secara terpadu melalui tema-tema kehidupan yang dijumpai peserta didik seharihari. Siswa diajak mengikuti proses pembelajaran transdisipliner yang menempatkan kompetensi yang diajarkan dikaitkan dengan konteks peserta didik dan lingkungan. Materi-materi berbagai mata pelajaran dikaitkan satu sama lain sebagai satu kesatuan, membentuk pembelajaran multidisipliner dan interdisipliner.

Buku ini merupakan penjabaran hal-hal yang harus dilakukan peserta didik untuk mencapai kompetensi yang diharapkan. Sesuai dengan pendekatan Kurikulum 2013, peserta didik diajak berani untuk mencari sumber belajar lain yang tersedia dan terbentang luas di sekitarnya. Peran guru dalam meningkatkan dan menyesuaikan daya serap peserta didik dengan ketersediaan kegiatan pada buku ini. Buku ini hanya sebagai panduan aktivitas pembelajaran, dan guru dapat memperkaya dengan kreasi dalam bentuk kegiatan lain yang sesuai dan relevan yang bersumber dari lingkungan alam, sosial, dan budaya di lingkungannya.

Struktur penulisan buku nampaknya dimaksudkan untuk memfasilitasi pengalaman belajar bermakna yang diterjemahkan melalui subjudul Ayo Cari Tahu, Ayo Belajar, Ayo Ceritakan, Ayo Bekerja Sama, Ayo Berlatih, Ayo Amati, Ayo Lakukan, Ayo Simpulkan, Ayo Renungkan, Ayo Kerjakan, Ayo Mencoba, Ayo Diskusikan, Ayo Bandingkan, Ayo Menulis, Ayo Temukan Jawabannya, Ayo Menaksir, Ayo Berkreasi, Ayo Analisis, Ayo Kelompokkan, Ayo Bernyanyi, Ayo Berpetualang, Tahukah Kamu, dan Belajar di Rumah.

Setiap awal subtema, terdapat lembar untuk orangtua yang berjudul Belajar di Rumah. Halaman ini berisi materi yang akan dipelajari, aktivitas belajar yang dilakukan anak bersama orangtua di rumah, serta saran agar anak dan orangtua bisa belajar dari lingkungan. Orangtua diharapkan berdiskusi dan terlibat dalam aktivitas belajar siswa. Saran-saran untuk kegiatan bersama antara siswa dan orangtua dicantumkan juga pada setiap akhir pembelajaran.

\section{Konten Hak-hak Anak Dalam Buku Siswa Kelas Lima Sekolah Dasar dengan Tema "Benda-benda Dilingkungan Sekitar"}

Konten hak-hak anak pada buku siswa kelas lima dengan tema "Mengenal Bendabenda Di Lingkungan Sekitar" akan disajikan sesuai dengan struktur buku, yaitu dimulai dengan subtema 1 sampai 3 secara berurutan dengan masing-masing subtema mengandung enam pembelajaran disajikan didalam Gambar 1. 


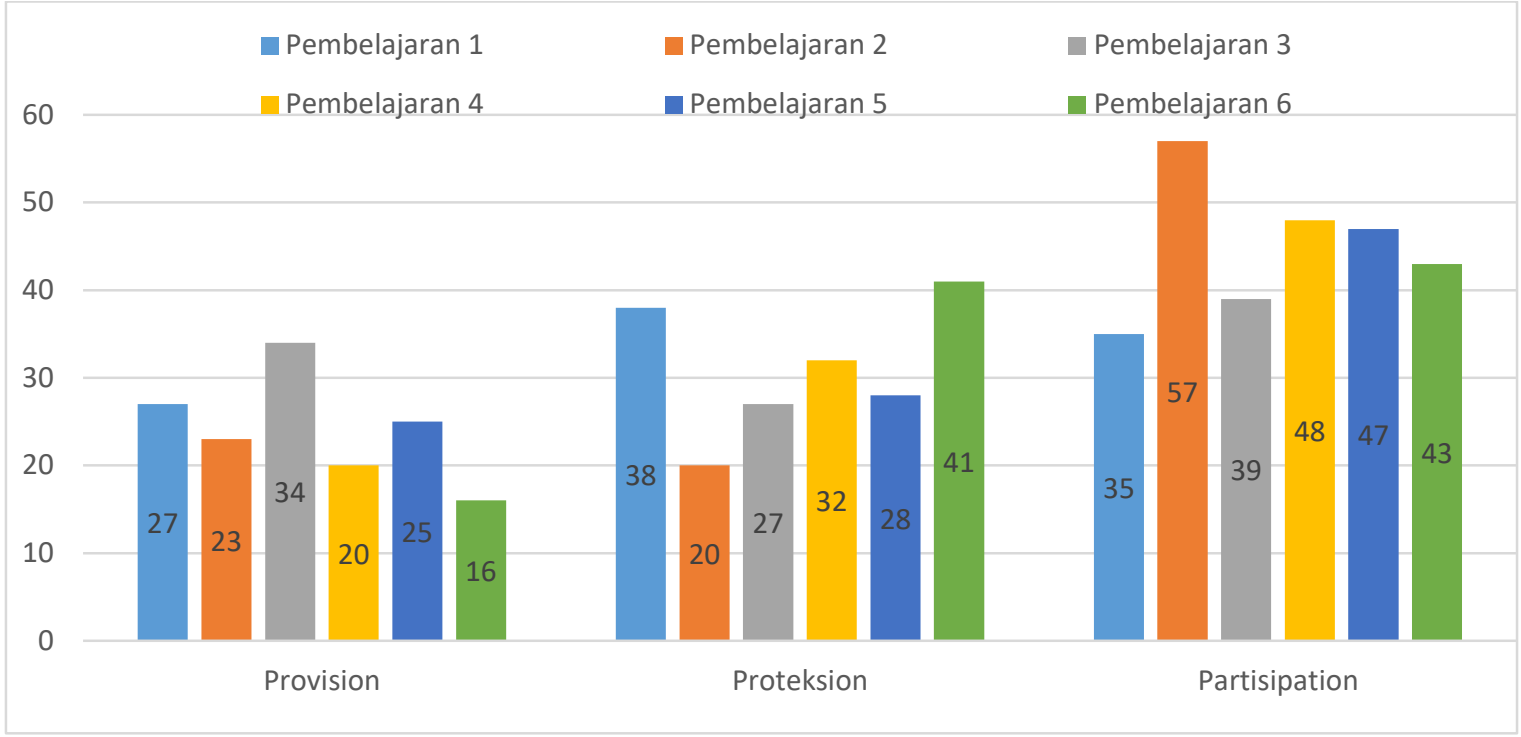

Gambar 1. Prosentase Konten Hak-hak Anak Pada Sub-tema Satu

Hak provision anak dalam berekspresi sudah diakomodasi pada seluruh kegiatan pembelajaran. kebebasan berekspresi sangat terlihat dalam sub judul ayo mencoba, ayo eksplorasi, ayo berlatih, dan ayo simpulkan. Indikator bebas mencari sumber pembelajaran hanya terlihat pada sub judul 2, 4, dan 5 dimana siswa diminta mencari contoh lain perubahan wujud benda dan mencari cara melakukan kegiatan fisik menangkap, menendang, dan melempar bola. Indikator penilaian otentik berdasarkan proses pembelajaran sangat terlihat pada setiap pembelajaran terutama pada sub judul ayo renungkan. Indikator pembelajaran inklusif tanpa diskriminasi hanya nampak pada pembelajaran 1, 5, dan 6 terutama pada sub judul ayo diskusikan. Indikator keterlibatan siswa dalam berkreasi sesuai minat, bakat dan tingkat kecerdasannya terlihat pada pembelajaran 1, 2, dan 6 dalam sub judul ayo bacalah, dan ayo eksplorasi.

Hak anak yang berkaitan dengan proteksi lebih cenderung hanya berbentuk pembelajaran yang berpusat pada anak dan pembelajaran menyenangkan. Sedangkan penerapan kedisiplinan dengan memperhatikan harga diri anak terlihat pada materi pembelajaran yang memuat penghormatan terhadap agama dan hak asasi manusia terlihat pada subbab 1 .

Indikator materi pembelajaran yang memuat penghormatan kepada sesama anak, termasuk anak berkebutuhan khusus terlihat pada sub judul ayo diskusikan dalam pembelajaran 1,2,5,dan 6 yang memberikan proporsi yang sama pada setiap siswa terlibat akttif dalam diskusi tentang tema yang sedang di ajarkan. Indikator materi pembelajaran yang memuat penghormatan terhadap tradisi dan budaya bangsa terlihat dalam pembelajaran 1, 2, 4, dan 6 dimana siswa diminta membuat ronce, mencari gambar beberapa kerajinan daerah, dan mengidentifikasi kerajinan daerah-daerah di Indonesia.

Hak anak yang berkaitan dengan partisipasi keseluruhan indikator terpenuhi dalam setiap kegiatan pembelajaran siswa. pemenuhan hak anak dalam berpartisipasi ini membuktikan bahwa buku siswa ini secara konsisten berbasis aktivitas yang sepenuhnya 
dilakukan siswa dengan guru sebagai fasilitator sebagaimana tercantum dalam kata pengantar buku.

Pada sub tema kedua hak provision anak dalam berekspresi terdapat pada seluruh kegiatan pembelajaran. Kebebasan berekspresi sangat terlihat dalam sub judul ayo eksplorasi, ayo berlatih, dan ayo simpulkan. Indikator kebebasan mengakses media belajar dan informasi terlihat pada sub judul 2, 3, 4, dan 6 dimana siswa diminta mengidentifikasi kebutuhan masyarakat di daerah tempat tinggalnya yang meliputi kebutuhan ekonomi, sosial, budaya, dan keamanan. Siswa juga diminta untuk mengidentifikasi barang-barang kebutuhan keluarga yang didatangkan dari daerah lain, dan barang-barang khas daerahnya. Disamping itu siswa juga diminta melakukan studi pustaka dan wawancara tentang pergeseran nilai-nilai dalam masyarakat akibat kemajuan teknologi. Indikator penilaian otentik berdasarkan proses pembelajaran terlihat pada setiap pembelajaran terutama pada sub judul ayo renungkan. Indikator pembelajaran inklusi tanpa diskriminasi hanya nampak pada pembelajaran 1, 2, dan 3 pada sub judul ayo diskusikan. Indikator keterlibatan siswa dalam berkreasi sesuai minat, bakat dan tingkat kecerdasannya terlihat pada pembelajaran 2, 4, 5 dan 6 dalam sub judul ayo bacalah, ayo berlatih, dan praktek membuat topeng maupun praktek berenang.

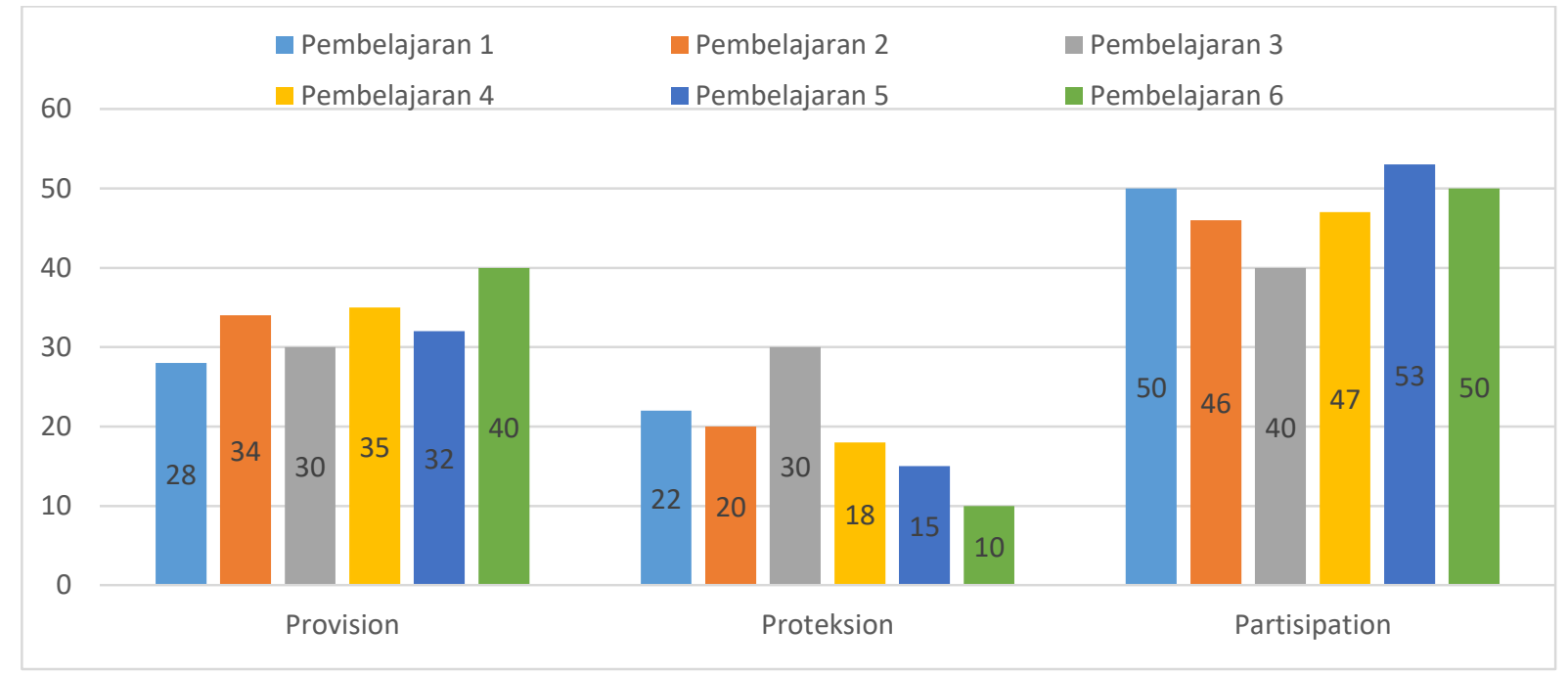

Gambar 2. Prosentase Konten Hak-hak Anak Pada Sub-tema Dua

Hak anak yang berkaitan dengan proteksi terlihat pada indikator pembelajaran yang berpusat pada anak dan pembelajaran dilakukan secara menyenangkan. Sedangkan penerapan disiplin dengan memperhatikan harga diri anak sama sekali tidak terlihat. Indikator materi pembelajaran yang memuat penghormatan terhadap agama dan hak asasi manusia hanya terdapat dalam pembelajaran 1 dan 3 yaitu pada pembahasan tentang dampak perubahan lingkungan akibat ulah manusia dan kegiatan mengidentifikasi kebutuhan manusia yang tidak dapat dipenuhi sendiri. Indikator materi pembelajaran yang memuat penghormatan kepada sesama anak, termasuk anak berkebutuhan khusus terlihat pada sub judul ayo diskusikan dalam pembelajaran 1 dan 4 yang memberikan proporsi yang sama pada setiap siswa terlibat aktif dalam diskusi tentang tema yang sedang di ajarkan. Indikator materi pembelajaran yang memuat penghormatan terhadap tradisi dan budaya 
bangsa termuat dalam pembelajaran 2, 3, 4, dan 6 yaitu siswa melakukan diskusi, eksplorasi, membaca, dan praktek membuat topeng berkarakter nasional, produk khas daerah, dampak positif dan negatif perkembangan teknologi, dan mendata nilainilai luhur pada masyarakat Indonesia.

Hak anak yang berkaitan dengan partisipasi terpenuhi dalam setiap kegiatan pembelajaran siswa. pemenuhan hak anak dalam berpartisipasi ini membuktikan bahwa buku siswa ini secara konsisten berbasis aktivitas yang sepenuhnya dilakukan siswa dengan guru sebagai fasilitator sebagaimana tercantum dalam kata pengantar buku. Dalam sub judul ayo amati, ayo eksplorasi, ayo diskusikan, ayo bacalah, ayo renungkan, ayo berlatih, dan kerjasama dengan orang tua memberikan peluang sebesar-besarnya pada siswa untuk aktif dan senang belajar untuk mengembangkan kepribadian, bakat, kemampuan menyelesaikan masalah, menghadrgai manusia dan dirinya, dan berpikir objektif.

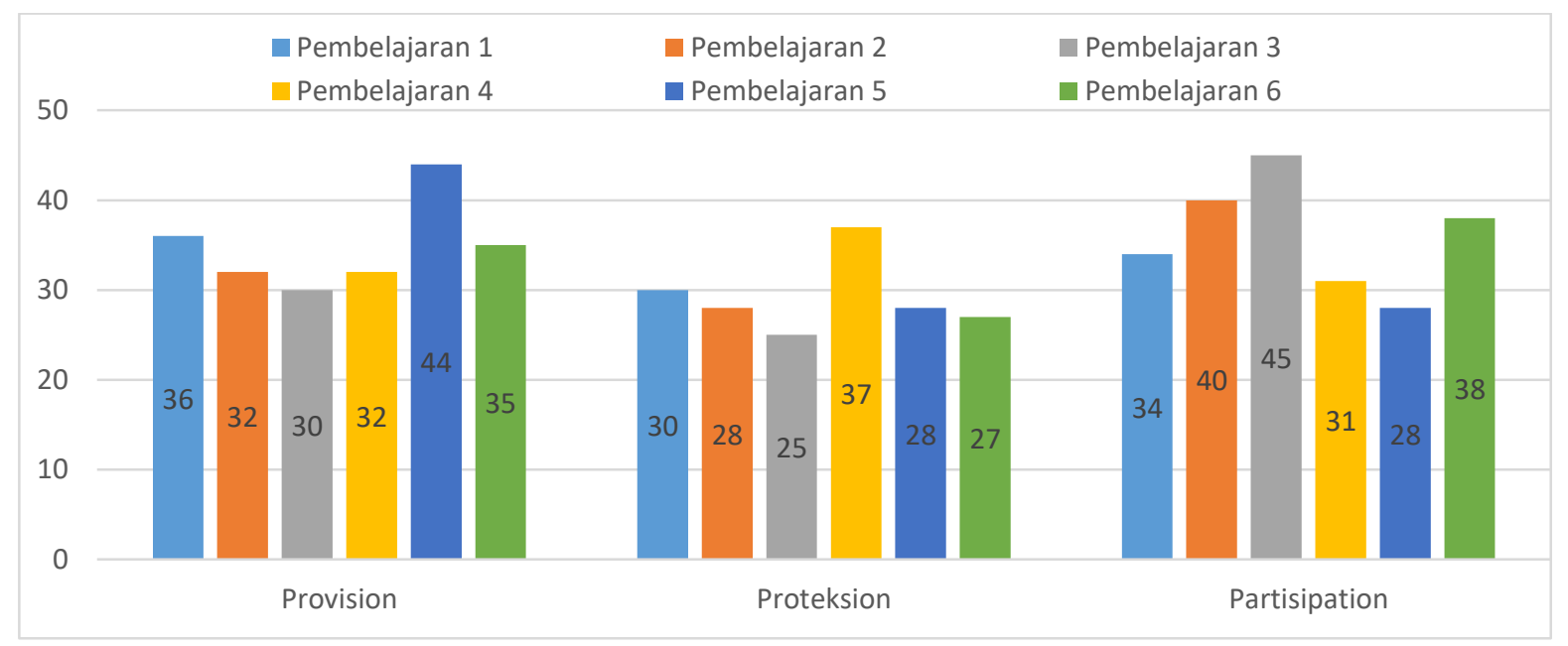

Gambar 3. Prosentase Konten Hak-hak Anak Pada Sub-tema Tiga

Pada sub tema ketiga hak provision anak dalam berekspresi terdapat pada seluruh kegiatan pembelajaran. Kebebasan berekspresi sangat terlihat dalam sub judul ayo diskusikan, ayo berlatih, dan ayo lakukan. Indikator kebebasan mencari sumber belajar dan informasi juga terdapat pada seluruh pembelajaran dimana siswa diminta mencari perbedaan dan ciri-ciri sair dan pantun; mencari kosa kata yang sulit; perbedaan antara gambar dekorasi, karikatur, dan ilustrasi; mengidentifikasi permainan tradisional, makanan tradisional,dan produk budaya lokal. Indikator otentik assessment and evaluation base learning process terlihat pada setiap pembelajaran terutama pada sub judul ayo renungkan. Indikator inclusive learning and non diskrimination hanya nampak pada pembelajaran 1,2 , dan 3 pada sub judul ayo diskusikan. Indikator keterlibatan siswa dalam berkreasi sesuai minat, bakat dan tingkat kecerdasannya terlihat pada pembelajaran 4 dalam sub judul ayo membaca tentang cara pandang manusia dan lingkungan yang dinamis.

Hak anak yang berkaitan dengan proteksi sangat terlihat pada indikator pembelajaran yang berpusat pada anak, pembelajaran 
dilakukan secara menyenangkan, dan materi yang memuat penghormatan terhadap tradisi dan budaya. Pada setiap pembelajaran mengandung materi yang berkaitan dengan mencintai budaya Indonesia seperti syair, pantun, permainan tradisional, karakter punakawan, identifikasi, produk budaya lokal, pertunjukan wayang kulit, dan bangga menggunakan produk Indonesia. Sedangkan penerapan disiplin denga memperhatikan harga diri anak hanya terdapat dalam pembelajaran 2 dan 5 yaitu dalam sub judul ayo lakukan menggambar sesuai dengan langkah-langkah yang ditentukan (membuat sketsa, gambar konkrit, dan mewarnai) dan sub judul berlatih bermain kasti serta berlari tumi kedepan-kebelakang. Indikator materi pembelajaran yang memuat penghormatan terhadap agama dan hak asasi manusia terdapat dalam pembelajaran 1 dan 4 yaitu pada pembahasan tentang berempati pada korban banjir dengan menyumbangkan sebagian harta, dan materi menghargai, menghormati, rukun dan kebebasan berpendapat tentang manusia dan lingkungan yang bersifat dinamis. Indikator materi pembelajaran yang memuat penghormatan kepada sesama anak, termasuk anak berkebutuhan khusus terlihat pada sub judul ayo diskusikan dalam pembelajaran 1,3,4 dan 6 yang memberikan proporsi yang sama pada setiap siswa terlibat aktif dalam diskusi dan berlatih. Indikator materi pembelajaran yang memuat penghormatan terhadap tradisi dan budaya bangsa termuat dalam seluruh pembelajaran, karena pada subtema ketiga ini materi ke Indonesian sangat dominan.

Hak anak yang berkaitan dengan partisipasi keseluruhan indikator terpenuhi dalam setiap kegiatan pembelajaran siswa. pemenuhan hak anak dalam berpartisipasi ini membuktikan bahwa buku siswa ini secara konsisten berbasis aktivitas yang sepenuhnya dilakukan siswa dengan guru sebagai fasilitator sebagaimana tercantum dalam kata pengantar buku. Dalam sub judul ayo amati, ayo eksplorasi, ayo diskusikan, ayo bacalah, ayo renungkan, ayo berlatih, dan kerjasama dengan orang tua memberikan peluang sebesar-besarnya pada siswa untuk aktif dan senang belajar untuk mengembangkan kepribadian, bakat, kemempuan menyelesaikan masalah, menghadrgai manusia dan dirinya, dan berpikir objektif.

Merujuk pada kompetensi yang diharapkan dari lulusan SD/MI dalam kurikulum 2013 yaitu siswa memiliki kemampuan berpikir dan tindak yang produktif dan kreatif dalam ranah abstrak dan konkret, maka konstruk buku siswa ini sudah didesain sesuai dengan tujuan tersebut. Materi dalam buku dirancang melalui proses pembelajaran tematik integratif berbasis discovery learning, project based learning, dan problem solving. Melalui pengetahuan tentang desain dan konstruk buku siswa kelas lima tema 1 ini, maka dapat diperoleh informasi mengenai pemenuhan hak-hak anak dalam konten bahan ajar siswa.

Tiga hak utama anak menurut CRC adalah provision, protektion, dan participation yang terkandung dalam buku siswa kelas lima tema 1 pada kurikulum 2013 secara keseluruhan dapat dikatakan sudah terkandung dalam materi pembelajaran siswa. Proses pembelajaran transdisipliner dengan menggabungkan materi berbagai mata pelajaran sebagai satu kesatuan yang membentuk pembelajaran multidisipliner dan interdisipliner pada kurikulum 2013 secara tidak langsung membutuhkan konsep pembelajaran yang memberikan jaminan kebebasan berekspresi, Kebebasan untuk mengakses media dan sumber informasi, 
penilaian otentik dan evaluasi proses pembelajaran dasar, Student Center. Pembelajaran dilaksanakan secara menyenangkan, Belajar dengan melakukan, Pembelajaran Aktif dan Bermain Aktif, dan Kebebasan beropini dan hak untuk didengar dalam semua hal pribadi.

Indikator-indikator yang jarang mendapatkan porsi dalam buku siswa kelas lima tema 1 ini adalah pembelajaran inklusif dan non diskriminasi; kedisiplinan dengan memperhatikan martabat dan harga diri; materi pembelajaran memuat penghormatan terhadap agama dan hak asasi manusia; materi pembelajaran memuat penghormatan kepada sesama anak; termasuk anak-anak yang berkebutuhan khusus; dan keterlibatan siswa dalam berkreasi sesuai dengan minat, bakat, dan tingkat kecerdasannya. Memang cukup rumit ketika harus dimasukkan dalam materi ajar. Indikator-indikator tersebut dapat diberikan kepada siswa dalam praktik pembelajaran, namun hal tersebut membutuhkan kesadaran dan pemahaman yang kuat dari guru kelas tentang hak-hak anak sehingga konten hak anak yang belum tercover buku teks dapat dilengkapi dalam praktek pembelajaran.

Sebaran muatan hak-anak pada buku siswa ini secara langsung memberikan gambaran bahwa desain pendidikan nasional yang dirancang pemeritah sejalan dengan empat prinsip dasar tersebut harus diimplementasikan dalam sekolah ramah anak yang direkomendasikan oleh PBB maupun pemerintah Swedia, yaitu: Merubah arah proses pengajaran dan pembelajaran dari konsep top down menjadi botton up; Merubah pendekatan pengajaran dan pembelajaran dari teacher centre menjadi student centre; Kelas bukan hanya sebagai tempat pengajaran teoritis, tetapi harus menampakkan potret kehidupan sosial sesungguhnya yang dialami oleh manusia; Konsep transfer pengetahuan yang dijalankan harus mengandung interaksi yang hangat antar sesama siswa, guru, dan kondisi dunia yang sesungguhnya secara luas (Leo ULF, at all, 2014: 18-20).

\section{SIMPULAN}

Simpul yang dihasilkan dalam penelitian ini adalah pemerintah Indonesia secara konsisten telah menjalankan hasil konvensi hak anak PBB tahun 1989, baik secara yuridis maupun aplikatif. Tiga hak utama anak menurut CRC adalah provision, protektion, dan participation yang terkandung dalam buku siswa kelas lima tema 1 pada kurikulum 2013 secara keseluruhan dapat dikatakan sudah terkandung dalam materi pembelajaran siswa. Proses pembelajaran transdisipliner dengan menggabungkan materi berbagai mata pelajaran sebagai satu kesatuan yang membentuk pembelajaran multidisipliner dan interdisipliner pada kurikulum 2013 secara tidak langsung membutuhkan konsep pembelajaran yang memberikan jaminan kebebasan berekspresi, Kebebasan untuk mengakses media dan sumber informasi, penilaian otentik dan evaluasi proses pembelajaran dasar, Student Center. 


\section{DAFTAR PUSTAKA}

Bakker, Anton dan Achmad Charis Zubair. 1990. Metodologi Penelitian Filsafat, Yogyakarta: Kanisius.

Kattsoff, Lois O.1987, Pengantar Filsafat, terj. Soejono Sumargono, Yogyakarta: Tiara Wacana.

The Scottish Government. 2010. A Guide to Implementing Getting It Right For Every Child: Messages From Path Finders and Learning Partner. The Scottish Government, Edinburgh.

Vygotsky, L. S. 1978. Mind and Society: The Development of Higher Psychological Processes. Cambridge, MA: Harvard University Press.

Leo, ULF, at all. 2014). Enforcing Child Right Globally: Experiences and Reflections From The International TrainingPrograme on Child Right, Classroom and School Management. Sweden: Media-tryck, Lund University.

Kementerian Pendidikan dan Kebudayaan. 2014. Benda-benda Di Lingkungan Sekitar. Buku Tematik Terpadu Buku Siswa Kelas V SD/MI Tema 1. Jakarta: Kementerian Pendidikan dan Kebudayaan.

United Nations Convention on the Right of The Child/CRC) November, 20, 1989

Undang-undang No. 23 Tahun 2002 Tentang Perlindungan Anak.

Undang-undang No. 35 tahun 2014 Tentang Perubahan Atas Undang-undang Perlindungan Anak No. 23 Tahun 2002 Tentang Perlindungan Anak.

Peraturan Menteri Negara Pemberdayaan Perempuan dan Perlindungan Anak Nomor 8 Tahun 2014

Peraturan Menteri Negara Pemberdayaan Perempuan dan Perlindungan Anak Nomor 12 Tahun 2011 tentang Indikator Kabupaten/Kota Layak Anak

Habiby, Wahdan Najib. (2012). "Efektivitas Pelatihan Motivasi Untuk Menurunkan Tingkat Stres Siswa Kelas VI SDN Tahunan Dalam Menghadapi Ujian Nasional”. Jurnal Prima Edukasia, Vol. 1, No. 2, Tahun 2013. Yogyakarta: Pasca Sarjana Universitas Negeri Yogyakarta. https://journal.uny.ac.id/index.php/jpe/article/view/2637. 